\title{
Formation and Development of the Italian Vocal School from 16th to 19th Centuries
}

\section{Formación y desarrollo de la escuela vocal italiana de los siglos XVI al XIX}

Yulia Aleksandrovna Martynova

Kazan Federal University, Russia

ORCID: https://orcid.org/0000-0002-4568-8254

Dmitry Yevgenyevich Martynov

Kazan Federal University, Russia

ORCID: https://orcid.org/0000-0001-5385-1915

Alina Mikhailovna Sukhova

Kazan Federal University, Russia

ORCID: https://orcid.org/0000-0003-1073-3884

Rimma Nailevna Sabirova

Kazan Federal University, Russia

ORCID: https://orcid.org/0000-0001-9953-6961

Received 09-08-20 Revised 10-10-20

Accepted 20-12-21 On line 02-20-21

* Correspondence

Email:dmitrymartynov80@mail.ru
Citation:

\footnotetext{
Martynova Yulia Aleksandrovna, Martynov Dmitry Yevgenyevich, Sukhova Alina Mikhailovna, Sabirova Rimma Nailevna. (2021) Formation and Development of the Italian Vocal School from 16th to 19th Centuries. Propósitos y Representaciones, 9(SPE2), e1018. doi http://dx.doi.org/10.20511/pyr2021.v9nSPE2.1018
} 


\section{Summary}

The article is devoted to the development and formation of the Italian vocal schools in the era of the New Age. The most important aspects of the development of the Italian vocal school are the domination of castrate singers in the 18th century and their gradual ousting in the era of the romantic opera formation. During the 20th century, the internationalization of Italian opera and vocal teaching methods take place. The study is based on a complex of historical methods. The materials are of interest to researchers of vocal technology and cultural history.

Keywords: Histoty, Cultural studies, Italian vocal school, castrati, Napoli conservatory.

\section{Resumen}

El artículo está dedicado al desarrollo y formación de las escuelas vocales italianas en la era de la Nueva Era. Los aspectos más importantes del desarrollo de la escuela vocal italiana son el dominio de los cantantes castrados en el siglo XVIII y su gradual derrocamiento en la era de la formación de la ópera romántica. Durante el siglo XX, se produce la internacionalización de la ópera italiana y los métodos de enseñanza vocal. El estudio se basa en un complejo de métodos históricos. Los materiales son de interés para los investigadores de tecnología vocal e historia cultural.

Palabras clave: Histotia, Estudios culturales, Escuela vocal italiana, Castrati, Conservatorio de Napoli.

\section{Introduction}

In the 21st century in the era of informatization and globalization in conservatories and music academies, opera vocals are the most popular among other professions. Students seek music education either in Italy or from teachers who are skilled in bel canto.

Teaching vocal skill is the process of transferring the achievements, experience and skill of previous generations of music teachers who have created them for decades and sometimes centuries.

Italian vocal school is characterized by its style of performance, manner of sound science and the nature of singing sound.

The formation of the national Italian vocal school is associated with the historically established bel canto style, characterized by a smooth transition from sound to sound, and relaxed sound emission, beautiful and rich color of the sound, voice equalization in all registers, ease of sound science. Bel canto requires from the singer a perfect technique of controlling a voice: immaculate cantilena, thinning, masterly coloratura, emotionally rich beautiful singing tone.

With the advent of the first operas, it was precisely in the depths of the operatic genre in Italy that the bel canto style evolved throughout the long history, which absorbed the best qualities of Italian singing art and became a reference for European opera singers. The techniques of the Italian vocal school were in many ways organic and natural. Mastering the bel canto technique allowed singers to overcome all the difficulties of operatic roles. For the Italian school, the most important thing was not the presence of natural singing resources in the singer, but the development of appropriate "mechanisms" in it, "creating an instrument" as a condition for mastering the singing sound (D. Lauri-Volpi, P. Guetta and others).Accordingly, mastery of skill and singing technique is a difficult process in the training of the singer, combining theatrical and musical-dramatic elements. 


\section{Methods}

The relevance of the topic is determined not only by art criticism, but by a much wider context also. The problem field includes theater studies and general issues of artistic culture.

The study is based on general scientific principles:

- Historical method within the framework of a systematic approach allows using the source study, chronological and musicological research methods;

- Systematic approach allowsconsidering the phenomenon of a single musical and educational space, to complete the elements of the musical and pedagogical system in the process of its reconstruction with a lack of historical data.

Also in the work the critical method was used - the theoretical analysis of methodical materials, pedagogical ideas and approaches; historical genetic and biographical methods.

\section{Results}

The academic manner of singing appeared in Italy at the end of the $16^{\text {th }}$ century when the first operas "Daphne" and "Eurydice"were created by J. Peri. A new synthetic genre became the outcome of the Renaissance, and there wasa need for performers owning a new style of singing. In Italy there were orphanages where children were given religious education, taught reading, writing and crafts. The first conservatory (then another shelter) Santa Maria di Loreto opened in 1537 in Naples. After that Santa Maria della Pieta deiTurchini (1584), Dei Poveri di Gesu Cristo (1589) and the Sant'Onofrio a Capuana (1600) were founded. Neapolitan conservatory teachers were outstanding composers of the time: F. Provenzale, A. Scarlatti, N. Porpora, L. Leo, F. Durante and etc. Many of them were graduates of conservatories themselves: Provenzale studied in Pieta, Porpora - in Loreto, Durante - in Sant'Onofrio (Polyakova, 2011).

In the conservatories of Naples, Santa Maria di Loreto (1535), Pieta deiTurchini (1584), Poveri di Gesu Cristo (1589), Sant'Onofrio in Capuana (1600) worked and brought fame to these conservatories, famous maestro: Francesco Durante (1684-1755), NiccolòPorpora (1686-1768), DomenicoGizzi (1687-1745), Leonardo Vinci (1690-1730), Francesco Feo (1691- 1761), Leonardo Leo (1694-1744), Giovanni Battista Pergolesi (1710-1736), NiccolloYomelli (17141774), TommasoTraetta (1727-1779), NiccolòPiccini (1728-1800), Antonio Sacchini (17301786), Giovanni Paisiello (1741-1816), DomenicoCimarosa (1749-1801), GaspareSpontini (1774-1851) and others.

The largest composer and teacher N. Porporabrought the glory to the Neapolitan vocal school and prepared such great vocal masters as castratiFarinelli, Caffarelli, F. Salimbeni (c. 1712 - 1751), soprano Gabrieli and others.

Boys studied in the Neapolitan conservatories, and only Sant'Onofriooffered a special home for girls. The conservatory accepted boys at the age of eight up to ten, sometimes up to fourteen years old, who could remain within the walls of an educational institution until the age of 20-22 (Salikhov et al., 2018).

The main method used by teachers was the method of "reciprocal learning" used in Neapolitan conservatories since old times. In the process of mastering singing or compositional art young musicians acquired the skills of pedagogical work. Giving lessons to their peers, they themselves comprehended even better and memorized acquired knowledge and polished skills, and tried and tested methods teaching then successfully applied after graduating from the conservatory, becoming a full maestro.

Training in conservatories was based on the following principles: first year pupils practiced solmization without intonation, they just uttered the names of the notes, tapping the rhythm. When the voice had been taught, the boys were allowed to sing solfeggio and sing solo. Exercises in solfeggio continued for several years, they lasted exactly as much as the teachers 
considered necessary. Vocalists in turn were sent to different classes depending on the type of a voice: soprano, contralto, tenor or bass.

Taking Alessandro Scarlatti's adviceDomenicoGizziestablished a special class of singing for the first time in 1720 at the Sant'Onofrio Conservatory. His famous discipleGioacchino Conti from Arpinotook the nameGizziello to honor his mentor.

At the end of the $18^{\text {th }}$ century there were three conservatories in Naples that numbered about ninety (Saint-Onofrio), one hundred and twenty (PiettadeiTurchini) and two hundred (Santa Maria di Loreto) people. Such figures were reported to Charles Burney in 1770 by NiccolòPiccinni.Apart from the four Neapolitan Conservatories of Santa Maria di Loreto (1535), Pieta deiTurchini (1584), Poveri di Gesu Cristo (1589), Sant'Onofrio in Capuana (1600) there were many other similar schools all over Italy (Polyakova, 2011).

The Neapolitan Conservatories were unquestionably not the only ones but one of the most important vocal education institutions in Italy, especially at the end of the 17th century and throughout most of the 18th century.

The conservatories of Naples were considered the best, but also in other Italian cities there were excellent music schools run by outstanding musicians and excellent teachers. In Rome it is, above all, the famous VirgilioMadzokki, Fedi and Amadori, in Bologna - Pier Francesco Tosi, Francesco Antonio Pistocchi and Antonio Maria Bernacchi. There was a famous school of Francesco Sang in Modena, in Genoa - Giovanni Paita, in Milan - Francesco Brivio, in Florence Francesco Redi. Venetian Republic in this series was some of the exceptions, as its musical educational institutions were intended mainly for girls and were called "Ospedagli" ("hospitals"), most of who functioned at monasteries, basilicas, temples, but their activities were not so well documented and studied accordingly (Kapur \& Alinkina, 2016).

Rome and Bologna were interested in educating the castrati. The high level of education was provided in the papal cities: primarily in a famous school of VirgilioMadzzoki, as well as the schools of Fedi and Amadori. There was a no less famous school of Tosi and Pistocchi in Bologna: both were castrati and decided to devote part of their life to the education of young singers - both castrates and others (Barbier, 1989).

The history of the vocal art has forever entered the names of the most prominent castrati singers like Gaetano Cafarelli (real name - Gaetano Majorano) and Carlo Farinelli (real name Carlo Throws). The historical victory of the tenors over castrated singers occurred in 1792, when at the premiere of the opera by D. Cimarosa "The Secret Marriage" a tenor Giuseppe Viganoni made a success (Vanherle, 2002).

Vocal opera art of the 19th century and old times of national vocal schools is distinguished by their certain convergence, which culminated in 20th century by universalization of vocal. With the undoubted leadership of Italy, the opera industry and, most importantly, pedagogy gradually became more and more international. Therefore, it is inappropriate to consider development of various European national schools in isolation (the exception, in part, is Germany due to the phenomenon Wagner's creativity). This, among other things, contributed to rapprochement of Italian and French (leading European operatic powers) composing tradition, which resulted in the emergence of genres such as large opera and then lyrical opera (Bloem-Hubatka, 2012; Miller, 1997; Sanguinetti, 2012).

Among the most famous vocal teachers of the XIX century is Francesco Lamperti (18111892), to whose school belonged such artists as Albani (Canadian singer, French origin), D. Artoux, A. de Lagrange, Morel (France), Zembrich(Poland), I. Campanini, S. Cruvelli, R. Pantaleoni (Italy), Tikhachek, T. Stolz (Czech Republic), etc. He has Dodonov, Everardi, Pryanishnikov, N. Figner and other Russian singers also improved. In 1850-1875 Lamperti taught in Milan Conservatory, wrote a number of theoretical works. Among the basic principles 
Lamperti- the statements that have become aphorisms "the school of singing is a schoolof breathing", "those who cannot not sing legato, do not sing at all".

Many years of activity have been fruitful in the field of pedagogy for Italian singer Antonio Cotogni, who brought up brilliant artists of the $19^{\text {th }}-$ firsthalf of $20^{\text {th }}$ centuries. Among his outstanding students is a Pole J. deReszke, the Italians MattiaBattistini, BeniaminoGigli,GiacomoLauri-Volpi,CarloGaleffi. He sang as a part of Italian Opera in St. Petersburg (1872 - 1894), and in 1894-1898 was a professor of the St. Petersburg Conservatory.

Prominent Italian vocalists, whose career was formed before the end of the 19 century, should be noted. They include such femalesingers asBellinzoni, Julia Grizi, Georgi-Righetti, Catalani, Pasta, Patti, singers Galli, Varezi, Lablash, Mazini, Mario, Marconi, Nozzari, Ronconi, Roubini, Stanio, Tamano, Tamberlic, Tamburini (Tsodokov, 1999).

\section{Discussion}

An array of studies on the history of vocal education, the formation and development of the Italian vocal school can be classified into several positions. Monographic studies exist mainly in English, Italian and French. Fundamental works were published in the 19th century, especiallyBurney's "Memoirs" (1832) and Florimo"Scuola musicale di Napoli". Collective monographic studies published also in Russia, which consider the development of Italian opera art, are little known. In translation into Russian, both memoirs and theoretical works of singers from the Italian school were published (Fucito, 2013; Lauri-Volpi, 1977).

The Leningrad Publishing house"Muzyka" published a series of collections of articles entitled "Issues of Vocal Pedagogy", which cover the history, practice and theory of vocal pedagogy, as well as the vocal and aesthetic principles of famous Russian, Soviet and foreign teachers. The entire array of studies created in the Soviet and post-Soviet periods are clearly divided into three streams according to the methodology used by their authors: works of a purely historical nature, musicological and musical pedagogical. Among the latter, we should highlight the methodological manual of L.K.Yaroslavtsev, which focuses on the national peculiarities of the opera, on the originality of vocal writing, on the characteristic features of the vocal parts of operas, i.e., on the tasks that were set in different historical periods of time (Yaroslavtseva et al., 1981).

Several dissertation studies were devoted to the vocal (and related) problems, one of the first was the study of V.I. Yushmanov for the degree of Doctor of Art History, defended in 2004. The first chapter dealt with the structure of the singing apparatus of the opera singer. In the second chapter, the psychotechnics of the management of the background process was considered. The third chapter presents the methodological foundations of the development of the singing apparatus (Yushmanov, 2004).

In 2011, N.I. Polyakova defended thePh.D. (candidate) dissertation "Solo Academic Children's Singing: Protection and Voice Development, Choice of Repertoire" for the degree in Art Criticism (Polyakova, 2011). The second chapter of the thesis examined the development of the Italian school, as well as vocal education in Italy of the 17th - 18th centuries and methodological aspects of the specifics of the two-register bel canto. In the third chapter, the author considers the formation of academic singing skills in the process of mastering vocal repertoire.

\section{Summary}

Thus, the formation of the Italian vocal school is associated with the opening of the first conservatories in Naples, such as Santa Maria di Loreto (1537), Santa Maria della Pieta deiTurchini (1584), Dei Poveri di GesuCristo (1589) and the Sant'Onofrio a Capuana (1600). Grammar, Rhetoric, Theology and Philosophy were taught in conservatories, but the main ones were musical subjects. Outstanding composers of the time worked in the conservatories of Naples: F. Provenzale, A. Scarlatti, N. Porpora, L. Leo, F. Durante, and others. 
In each of the conservatories there were two main maestri di capella: one taught composition and the other singing. The rest (maestrisecolari) were responsible for instrumental training. The pedagogical process was based on the popular method of "mutual learning".In 1720, a special class of singing at the Conservatory of SaintOnofrio was opened.

The beginning of $18^{\text {th }}$ century is the heyday of music education in Italy. The decline of music education is noticeable in the last decades of $18^{\text {th }}$ century. The main reason for this is the incorrect selection of the vocal repertoire.

Obviously, the Neapolitan Conservatories were, although not the only ones, but among the most important institutions of vocal education in Italy, especially at the end of $17^{\text {th }}$ century and throughout most of $18^{\text {th }}$ century.

Thus, having considered the peculiarities of the development of the Italian vocal school, we can note that the type, the classification of voices, firmly held out their concepts in the period of the $19^{\text {th }}$ - early $20^{\text {th }}$ centuries. In the period of $19^{\text {th }}$ - early $20^{\text {th }}$ centuries there is a gradual ousting of castrati due to the fact that sounding of their voices ceased to meet the artistic tasks of a new, romantic opera. formed.

The principles of improving the vocal apparatus, which are currently relevant, have been

With the undoubted leadership of Italy, the opera industry and, most importantly, pedagogy gradually became more and more international. Therefore, it is inappropriate to consider the development of various European national schools of the $19-20^{\text {th }}$ centuries in isolation (the exception, in part, is Germany due to the phenomenon of Wagner's creativity). This, among other things, was promoted by a certain rapprochement of the Italian and French (leading European operatic powers) composer traditions that contributed to the emergence of such genres as the big opera and then the lyrical opera.

The first third of the $19^{\text {th }}$ century the era of "developed bel canto." If in the $18^{\text {th }}$ century the main task of bel canto singing was virtuosity, then the beginning of the $19^{\text {th }}$ century foreshadowed the search for other methods of singing, contributing to the expression of more individualized feelings and characters, the lyric and dramatic nature of operatic action. Such singing required a variety, a quick change of dynamic and dramatic shades that could not be realized with the help of only virtuosity and an abundance of coloratura. This task was more efficiently performed by rigmarole singing, and then wider melodic breathing, of which Bellini is considered to be the ancestor.

There is also a confrontation with virtuosity, for example, the composer Rossini in his musical texts writes in detail in the vocal parts all the notes necessary for decoration, which excludes the possibility for soloists to improvise and add on their own various kinds of coloratura for the demonstration of personal mastery.

\section{Conclusions}

Types of voices and their classification, which were formed in the period of the 19thbeginning of the 20th centuries firmly gained their concepts, and in the future, the voices did not undergo revolutionary changes (Bikeyeva et al., 2019; Sanguinetti, 2012). There was a final separation of the baritone and bass, the corresponding positions were taken by the tenor, contralto and mezzo-soprano. The female soprano, which had previously been subjected to various kinds of restrictions, both artistic and social, was even more firmly established. The time of prima donnas came. The effective use of the possibilities of voices contributed to the achievement of vocal pedagogy of this era, which formed the basic principles for the improvement of the vocal apparatus, which are still relevant today. 


\section{Acknowledgements}

The work is performed according to the Russian Government Program of Competitive Growth of Kazan Federal University.

\section{References}

Barbier, P. (1989). Histoire des castrats. Paris: Grasset, 276 pp. (In French)

Bikeyeva, N., et al. (2019). Images of Power in the societies of Antiquity and the Middle Ages: symbols and ritual practices of the East and West. Journal Of Politics And Law, 12(5), 8397.

Bloem-Hubatka, D. (2012). The Old Italian School of Singing: A Theoretical and Practical Guide. Jefferson: McFarland, $219 \mathrm{pp}$.

Fucito, S. (2013). Caruso and the art of singing. Theclassics US, 209 pp.

Kapur, A.D., \& Alinkina, E.V. (2016). Vocal education in Italy in the $17^{\text {th }}$ - first half of the $19^{\text {th }}$ century. Moscow, $89 \mathrm{pp}$.

Klingstedt, P.T. (1949). Common Sense in Vocal Pedagogy as Prescribed by the Early Italian Masters. Edwards brothers, Incorporated, lithoprinters, $71 \mathrm{pp.}$

Lauri-Volpi, G. (1977). Vocesparalelas. Bologna: Bongiovanni, 238 pp. (In Italian)

Miller, R. (1997). National Schools of Singing: English, French, German, and Italian Techniques of Singing Revisited. Lanham: Scarecrow Press, 237 pp.

Polyakova, N.I. (2011). Solo and academic child's singing: Ph.D. dissertation. Moscow, 234 pp. (In Russian)

Ruffo, T. (1984). La mia parabola: memorie. Roma: Staderini, 444 p. (In Italian)

Salikhov, Anton N., Khurmatullina, Rezeda, K., \& Shakurova, L. (2018). The Content of Individual Creative Style of a Music Teacher. The Journal of Social Sciences Research, 1, 271-274.

Sanguinetti, G. (2012). The Art of Partimento: History, Theory, and Practice. Oxford University Press, $420 \mathrm{pp}$.

Tsodokov, E. (1999). Opera: An encyclopedic dictionary. Moscow: Kompozitor publ. 578 pp. (In Russian)

Vanherle, F.P. (2002). Castrati: The History of an Extraordinary Vocal Phenomenon and a Case Study of Handel's Opera Roles for Castrati Written for the First Royal Academy of Music (1720-1728). D.M.A. University of Texas at Austin.148 pp.

Yaroslavtseva, L.K. et al. (1981). Foreign vocal schools: Textbook on the history of vocal art. Moscow: GMPI, 90 p. (In Russian)

Yushmanov, V.I. (2004). Singing instrument and vocal technique of opera singers: Ph.D. dissertation. St. Petersburg, 262 pp. (In Russian) 